Columbia Law School

Scholarship Archive

2003

\title{
Engineering a Venture Capital Market: Lessons from the American Experience
}

Ronald J. Gilson

Columbia Law School, rgilson@law.columbia.edu

Follow this and additional works at: https://scholarship.law.columbia.edu/faculty_scholarship

Part of the Business Organizations Law Commons, Contracts Commons, and the Law and Economics Commons

\section{Recommended Citation}

Ronald J. Gilson, Engineering a Venture Capital Market: Lessons from the American Experience, 55 STAN. L. REV. 1067 (2003).

Available at: https://scholarship.law.columbia.edu/faculty_scholarship/993

This Article is brought to you for free and open access by the Faculty Publications at Scholarship Archive. It has been accepted for inclusion in Faculty Scholarship by an authorized administrator of Scholarship Archive. For more information, please contact scholarshiparchive@law.columbia.edu. 


\title{
ARTICLES
}

\section{Engineering a Venture Capital Market: Lessons from the American Experience}

\author{
Ronald J. Gilson*
}

INTRODUCTION.

I. AN OVERVIEW OF THE ORGanizational AND CONTRACTUAL STRUCTURE OF U.S. VENTURE CAPITAL.

II. The Economics of Venture Capital Contracting: The Special PROBLEMS OF UNCERTAINTY, INFORMATION ASYMMETRY, AND AGENCY COSTS.

A. The Venture Capital Fund-Portfolio Company Contract .................. 1078

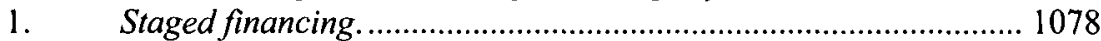

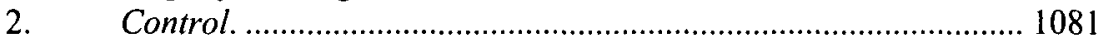

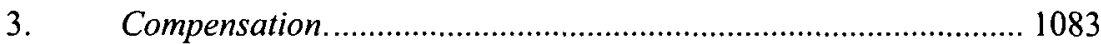

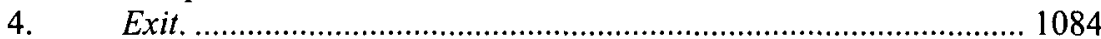

5. Reliance on implicit contract: The role of the reputation market. 1085

B. The Investor-Venture Capital Fund Contract ................................... 1087

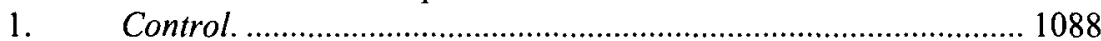

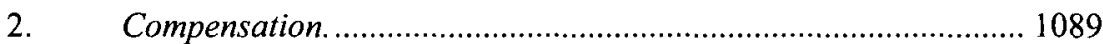

3. Mandatory distributions and fixed term.................................... 1089

C. Braiding of the Venture Capital Fund-Portfolio Company and the

Investor-Venture Capital Fund Contracts .................................................... 1091

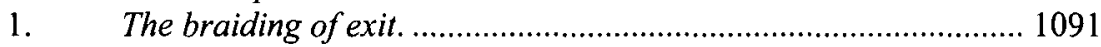

2. The braiding of the reputation market...................................... 1092

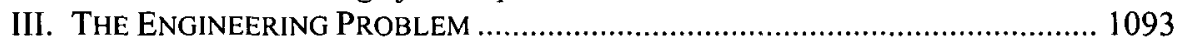

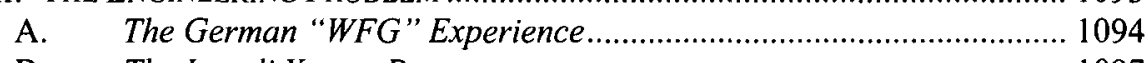

B. The Israeli Yozma Program ......................................................... 1097

* Charles J. Meyers Professor of Law and Business, Stanford University, and Marc \& Eva Stern Professor of Law and Business, Columbia University. An earlier version of this paper was given as the 2001-2002 John R. Raben Fellowship Lecture at the Yale Law School; at a Columbia Law School conference on Global Markets, Domestic Institutions; and at a Federal Reserve Bank of Atlanta conference on Venture Capital Markets: What's Next. I am grateful to participants in these programs, and to Theodor Baums, Victor Goldberg, Henry Hannsman, Michael Klausner, and George Triantis, for helpful comments. 1 owe a special debt to Zohar Goshen, whose work on the Israeli venture capital market was invaluable. 
C. The Chilean CORFU Program 1098

IV. A TEMPlate for GovernMENT ENGINEERING OF A VENTURE CAPITAL

MARKET

QUALIFICATIONS AND CONCLUSION 1101

\section{INTRODUCTION}

The venture capital market and firms whose creation and early stages were financed by venture capital are among the crown jewels of the American economy. Beyond representing an important engine of macroeconomic growth and job creation, these firms have been a major force in commercializing cutting-edge science, whether through their impact on existing industries as with the radical changes in pharmaceuticals catalyzed by venture-backed firms' commercialization of biotechnology, or by their role in developing entirely new industries as with the emergence of the Internet and World Wide Web. The venture capital market thus provides a unique link between finance and innovation, providing start-up and early stage firms-organizational forms particularly well-suited to innovation-with capital market access that is tailored to the special task of financing these high-risk, high-return activities. ${ }^{1}$

It is hardly surprising, then, that other countries have sought to emulate American success in developing an effective venture capital market. ${ }^{2}$ At a time when developing countries are increasingly losing manufacturing jobs to low wage countries, and when low wage countries seek industries that depend on more than just cheap labor, creating a venture capital market has become the holy grail of economic development. ${ }^{3}$

In this Article, I seek to identify the core of the U.S. venture capital contracting model, and then assess the extent to which this model provides

1. For example, Kortum and Lerner report that venture capital-backed firms produce not only more patents, but also more valuable patents than firms without venture capital backing. Samuel Kortum \& Joshua Lerner, Assessing the Contribution of Venture Capital to Innovation, 31 RAND J. ECON. 674, 674-75 (2000).

2. See Laura Bottazzi \& Marco Da Rin, Venture Capital in Europe and the Financing of Innovative Companies, 17 ECON. POL'Y 231, 231 (2002) ("[T]here now exists a wide consensus among economists, business leaders and policy-makers that a vibrant venture capital industry is the comerstone of America's leadership in the commercialization of technological innovation. A related and widely held belief is that the lack of venture capital hinders European firms from competing on equal footing.").

3. For European Union commentary, see, for example, Comm'n of the European Cmtys., Risk Capital: A Key to Job Creation in the European Union (1998) (on file with author); Final Report of the Committee of Wise Men on the Regulation of European Securities Markets (2001) (on file with author). At the Nice European Council of December 2000 , the European Union's fifteen heads of state characterized entrepreneurship as central to employment policy. Colin MaYer, KoEN Schoors \& Yishay YafEH, SOURCES OF FundS AND INVESTMENT ACTIVITIES OF VENTURE CAPITAL Funds: EVIDENCE FROM GERMANY, ISRAEL, JAPAN AND THE UK l (Soc. Sci. Research Network Elec. Paper Collection, Working Paper, 2002), available at http://papers.ssrn.com/sol3/ papers.cfm?abstract_id=314479. 
guidance in fashioning a venture capital market in other countries. This effort proceeds by a number of steps.

The analysis builds on what should be an uncontroversial premise-that the manner in which the U.S. venture capital market developed is not duplicable elsewhere. The U.S. venture capital market has a wildly idiosyncratic history that finds its origins in post-Gold Rush California, when Stephen Field, David Dudley Field's more successful younger brother, facilitated the adoption in California of his brother's failed New York Civil Code, and thereby planted the seeds for Silicon Valley through the Code's inexplicable prohibition of covenants not to compete. The locus then moved east, to the World War II Boston area research labs, and then west again with Frederick Terman's return to head Stanford's engineering school and his successful effort to sow the seeds of Silicon Valley by linking Stanford University and the emerging electronics industry through the creation of the Stanford Industrial Park, and then east once again with the post-World War II political decisions concerning how to finance retirement security. ${ }^{4}$

But while the path along which the U.S. venture capital market developed was surely idiosyncratic, the outcome of the development was not. The argument's most important step is to recognize that the keystone of the U.S. venture capital market is private ordering-the contracting structure that developed to manage the extreme uncertainty, information asymmetry, and agency costs that inevitably bedevil early-stage, high-technology financing. Start-up and early stage companies are peculiarly suited to commercializing innovation, yet the character of their organization and the nature of the activity present inherent barriers to their finance. The U.S. venture capital contracting model manages these barriers and thereby makes early stage financing feasible. The question, then, is whether the U.S. contracting template can be replicated elsewhere: Can we engineer a venture capital market?

The second step in the analysis takes up the engineering problem. Here the difficulty is that replicating the U.S. venture capital contracting structure confronts a daunting simultaneity problem. Three central inputs are necessary to the engineering process: capital, specialized financial intermediaries, and entrepreneurs. ${ }^{5}$ The problem is that each of these inputs will emerge if the other two are present, but none will emerge in isolation of the others.

4. Ronald Gilson, The Legal Infrastructure of High Technology Industrial Districts: Silicon Valley, Route 128, and Covenants Not to Compete, 74 N.Y.U. L. REV. 575, 588-89, 613-20 (1999).

5. Any capital market also requires a range of foundational attributes, like property rights, honest and effective courts, and the like. Detailing the general social and institutional infrastructure necessary to support a capital market of any sort is beyond my ambitions here. For an interesting assay of these issues with respect to the necessary preconditions for a stock market, see Bernard S. Black, The Legal and Institutional Preconditions for Strong Securities Markets, 48 UCLA L. ReV. 781 (2001). See also Andrzej Rapaczynski, The Role of the State and the Market in Establishing Property Rights, 10 J. ECON. PERSP. 87 (1996). 
This brings us to the third step: Who will be the engineer? The U.S. venture capital market developed organically, largely without government assistance and certainly without government design. Countries now seeking to develop a venture capital market must necessarily follow a different path than did the United States, and understandably look to government to provide direction when market forces are unlikely to solve the simultaneity problem. As a result, government programs are commonplace in countries seeking to develop a venture capital market. Most such programs, however, have been unsuccessful. 6 The reason, I will suggest, is that most government programs have tried to deal with the simultaneity problem by having the government both provide capital and act as the financial intermediary. Programs structured in this fashion fail because the government cannot respond to the trio of contracting problems inherent in early stage, high technology financing. Rather, a specialized financial intermediary is a necessary ingredient for which the government is not a substitute. The point is illustrated by discussion of three different government programs-one remarkably unsuccessful early effort in Germany; one more recent, more successful program in Israel; and a newly launched program in Chile.

The final step in the analysis describes an approach by which the government can help engineer a venture capital market. The approach recognizes that the key to the engineering task is solving the simultaneity problem without substituting the government, which cannot address the contracting problems of venture capital financing, for critical market participants.

\section{AN OVERVIEW OF THE ORGANIZATIONAL AND CONTRACTUAL STRUCTURE OF U.S. VENTURE CAPITAL}

The typical transactional pattern in the U.S. venture capital market is for institutional investors-pension funds, banks, insurance companies, and endowments and foundations - to invest through intermediaries, venture capital limited partnerships usually called "venture capital funds," in which the investors are passive limited partners. Venture capital funds are typically blind pools. At the time an institution decides whether to participate in a venture capital fund, it receives an offering memorandum that discloses the fund's investment strategy-for example, that the fund will specialize in a particular industry, like the Internet, or a distinct development stage, like early stage

6. Despite a large number of European government efforts, the European venture capital market remains a fraction of the size of the U.S. market. Controlling for the size of the economy, in 1995, U.S. venture capital financing was eight times the comparable European figure. Paul A. Gompers \& Josh Lerner, The Venture CaPITAl CyCle $326 \mathrm{n} .1$ (1999). In 2001, the difference was said to be five times, but that figure may be understated because of differences in definition of venture capital in the United States and Europe. Bottazzi \& Da Rin, supra note 2, at 232. 
investments. However, the particular companies in which the fund will invest are not yet known. Consistent with the legal rules governing limited partnerships, the limited partners may not participate in the day-to-day management. of the fund's business, including especially the approval of particular portfolio company investments. ${ }^{7}$ In this respect, the venture capital fund's governance structure formalizes the standard Berle-Means problem of the separation of ownership and control. ${ }^{8}$ The general partner (GP) puts up only one percent of the capital, but receives essentially complete control over all of it. ${ }^{9}$ The particular terms of the fund's governance are set out in the limited partnership agreement. ${ }^{10}$

The GP actually makes and monitors the venture capital fund's investments. The GP is typically itself a company comprised of investment professionals, which expects to continue in the venture capital market by raising successive funds after the capital in a particular fund has been invested in portfolio companies. This expectation, and the GP's investment in a business infrastructure, provides a powerful performance incentive. Commonly, the GP will begin seeking investors for a successor fund by the midpoint of the existing fund's fixed, typically ten-year, term. At the close of the partnership's fixed term, liquidation is mandatory. Indeed, the partnership will be in partial liquidation during much of its term because realized profits from exiting an investment are required to be distributed to the limited partners on an annual basis. ${ }^{11}$ The GP's principal contribution to the venture capital fund is expertise, not capital. This is reflected in the ratio of capital contributions. In most funds the GP contributes one percent of the fund's capital, while the limited partner investors contribute the remaining ninety-nine percent.

7. Under Delaware law, the limited partners can make certain extraordinary decisions, such as replacing the general partner or terminating the partnership. See DEL. CODE ANN., tit. 6, $\S 17-303(\mathrm{~b})(8)(\mathrm{a})$, (e) (2003). However, these rights are typically restricted by contract. See Michael J. Halloran, Gregg Vignos \& C. Brian Wainwright, Agreement of Limited Partnership, in 1 Venture Capital and Public OfFering Negotiation 1-1 to 1218 (Michael J. Halloran, Robert V. Gunderson, Jr., Jorge del Cavo \& Benjamin M. Vandegrift eds., 3d ed. 2002) (form of limited partnership agreement with commentary). Venture capital funds frequently do appoint advisory committees, usually made up of investor representatives, that monitor the fund's performance. See William A. Sahlman, The Structure and Governance of Venture-Capital Organizations, 27 J. FIN. ECON. 473, 493 (1990).

8. Adolf A. Berle, Jr. \& Gardiner C. Means, The Modern Corporation and PRIVATE PROPERTY (1932).

9. Even if one treated the venture capitalist's carried interest as a measure of the value of its human capital contribution, it is still putting up less than $20 \%$ of the capital but receiving complete control.

10. See Halloran et al., supra note 7, at 1-1 to 1-223. For an examination of the terms of such agreements, see Paul Gompers \& Josh Lerner, The Use of Covenants: An Empirical Analysis of Venture Partnership Agreements, 39 J. LAW \& ECON. 463 (1996).

11. Halloran et al., supra note 7, at 1-67 to 1-82; Sahlman, supra note 7, at 491-92. 
The GP's compensation is also skewed. The GP usually receives an annual management fee for its services, but the fee is relatively small, usually $2.5 \%$ of committed capital. ${ }^{12}$ The primary return to the GP is a carried interest-that is, a right to receive a specified percentage of profits realized by the partnership. Twenty percent is a common figure. ${ }^{13}$ The GP generally is paid its carried interest at the same time that distributions are made to the limited partners, subject to two limitations. First, general partners typically receive no distributions until the limited partners have received an amount equal to their capital contributions, sometimes with interest. Second, distributions to the GP are subject to certain "claw back" provisions that ensure that the order of distribution does not affect the ultimate percentage of profits received by the GP.

The venture capital fund's equity investments in portfolio companies typically take the form of convertible preferred stock. ${ }^{14}$ While not required by the formal legal documents, the fund is also expected to make important noncash contributions to the portfolio company. These contributions consist of management assistance, corresponding to that provided by management consultants; intensive monitoring of the portfolio company's performance which provides an objective view to the entrepreneur; and the use of the fund's reputation to give the portfolio company credibility with potential customers, suppliers, and employees. 15 While each investment will have a "lead" investor who plays the primary role in monitoring and advising the portfolio company,

12. Sahlman, supra note 7 , at 491. In most cases, the agreement provides for a breakpoint above which the management fee is reduced, based either on funds under management or the number of years after the partnership's formation. Halloran et al., supra note 7 , at $1-108$ to $1-116$.

13. GOMPERS \& LERNER, supra note 6, at 32; Halloran et al., supra note 7, at 1-51 to 166; Sahlman, supra note 7, at 491.

14. Paul Gompers, OWnership and Control in Entrepreneurial Firms: An Examination of Convertible Securities in Venture Capital InVestments 2, 314-15 (Harvard Business School, Working Paper, 1997) (on file with author); Sahlman, supra note 7, at 504. Steven Kaplan and Per Strömberg report that convertible preferred stock was used in $95 \%$ of a sample of 200 financing rounds in 118 portfolio companies made by 14 venture capital firms between 1996 and 1999. STEVEN N. KAPLAN \& PER STROMBERG, FinANCIAL

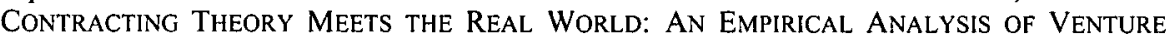
Capital Contracts 13 (Nat'l Bureau of Econ. Research, Working Paper 7660, 2000), available at http://www.nber.org/papers/w7660. Ronald Gilson and David Schizer argue that this consistency is driven by the tax efficiency of this capital structure in delivering high-powered incentives to management. Ronald J. Gilson \& David M. Schizer, Understanding Venture Capital Structure: A Tax Explanation for Convertible Preferred Stock, 116 HARV. L. REV. 874 (2003).

15. Bernard S. Black \& Ronald J. Gilson, Venture Capital and the Structure of Capital Markets: Banks Versus Stock Markets, 47 J. FIN. ECON. 243, 252-55 (1998); Thomas F. Hellman, Venture Capitalists: The Coaches of Silicon Valley, in THE SILICON VALLEY EdGE: A Habitat FOR INNOVATION AND ENTREPRENEURSHIP 276 (Chong-Moon Lee, William F. Miller, Marguerite Gong Hancock \& Henry S. Rowen eds., 2000); Thomas Hellman \& Manju Puri, Venture Capital and the Professionalization of Start-up Firms: Empirical Evidence, 57 J. FIN. 169 (2002). 
commonly the overall investment is syndicated with other venture capital funds that invest in the portfolio company at the same time and on the same terms. ${ }^{16}$

The initial venture capital investment usually will be insufficient to fund the portfolio company's entire business plan. Accordingly, investment will be "staged." A particular investment round will provide only the capital the business plan projects as necessary to achieve specified milestones set out in the business plan. ${ }^{17}$ While first round investors expect to participate in subsequent investment rounds, ${ }^{18}$ often they are not contractually obligated to do so even if the business plan's milestones are met; the terms of later rounds of investment are negotiated at the time the milestones are met and the prior investment exhausted. Like the provision of noncapital contributions, an implicit, not explicit, contract typically governs the venture capital fund's right and obligation to provide additional rounds of financing if the portfolio company performs as expected. The venture capital fund's implicit right to participate in subsequent rounds-by contrast to its implicit obligation to participate-is protected by an explicit right of first refusal. ${ }^{19}$

A critical feature of the governance structure created by the venture capital fund's investment in the portfolio company is the disproportionate allocation of control to the fund. ${ }^{20}$ In direct contrast to the familiar Berle-Means governance structure of outside investors having disproportionately less control than equity, the governance structure of a venture capital-backed early stage, high technology company allocates to the venture capital investors

16. Joshua Lerner, The Syndication of Venture Capital Investments, 23 FIN. MGMT. 16, 18 (1994).

17. See Paul A. Gompers, Optimal Investment, Monitoring, and the Staging of Venture Capital, 50 J. FIN. 1461, 1463-67 (1995).

18. Sahlman, supra note 7 , at 475 , reports that venture capital funds invest one third of their capital in new investments and two thirds in later round financing of companies already in their portfolios.

19. Kaplan and Strömberg report that some $15 \%$ of the financing rounds in their sample conditioned disbursement of a portion of the round on explicit contingencies. Many of these, however, are not inconsistent with the unconstrained option to abandon analysis in the text. First, in some number of these instances, subsequent financing was contingent on "no material deviation" from the business plan. Kaplan \& Strömberg, supra note 14, at 59 tbl.6. While such a formulation does operate to make exercise of the option to abandon reviewable by a court, it hardly represents state contingent contracting and still leaves the venture capitalist with a great deal of discretion. Since material changes in a business plan are predictable given the nature of an early stage business, in most cases the material deviation contingency will collapse into a pure option to abandon. Second, contingencies are keyed to readily observable and verifiable events like the issuance of a patent, or the hiring of a chief executive officer, again instances when a specific uncertainty can be specified and its resolution observed. Finally, Kaplan and Strömberg do not suggest that the venture capitalists are committed to provide future financing rounds even in the minority of rounds where explicit contingencies are found. Taken as a whole, their data leave intact the general proposition that venture financing is staged, without binding future commitments by existing venture investors.

20. See GOMPERS, supra note 14 (explaining the control mechanisms built into convertible venture financing). 
disproportionately greater control than equity. It is common for venture capital investors to have the right to name a majority of a portfolio company's directors even though their stock represents less than a majority of the portfolio company's voting power. ${ }^{21}$ Additionally, the portfolio company will have the benefit of a series of contractual negative covenants that require the venture capital investors' approval before the portfolio company can make important business decisions, such as acquisition or disposition of significant amounts of assets, or a material deviation from the business plan. The extent of these negative covenants is related to whether the venture capital investors have control of the board of directors; board control acts as a partial substitute for covenant restrictions. 22

These formal levers of control are complemented by the informal control elements that result from the staged financing structure. Because a financing round will not provide funds sufficient to complete the portfolio company's business plan, staged financing in effect delegates to the investors, in the form of the decision whether to provide additional financing, the decision whether to continue the company's project. ${ }^{23}$

Two final characteristics of investments in portfolio companies concern their terms and their expected performance. While these are not short-term investments, neither are they expected to be long-term. Because venture capital limited partnerships have limited, usually ten-year terms, ${ }^{24}$ GP's have a strong incentive to cause the fund's portfolio company investments to become liquid as quickly as possible. Assuming that the GP has invested most of a fund's capital by the midpoint of the fund's life, the GP then must seek to raise additional capital for a new fund in order to remain in the venture capital business. $^{25}$ Because the performance of a GP's prior funds will be an

21. In Gompers's sample of portfolio company investments, venture capital investors on average controlled the portfolio company's board of directors, but held only $41 \%$ of the equity. Id. at $334,350-51$ tbl.4. The venture capital fund's right to select a specified number of directors is contained in the portion of the portfolio company's articles of incorporation that sets out the rights, preferences, and privileges of the convertible preferred stock the investors receive. This portion of the articles will typically be added by amendment simultaneously with the closing of the venture capital investment. Lee F. Benton, Robert V. Gunderson, Jr. \& Julie M. Robinson, Hi-Tech Corporation: Restated Certificate of Incorporation, in I VENTURE CAPITAL AND PUBLIC OFFERING NEGOTIATION, supra note 7, at 8-1 to 8-55, sets out a standard form of restated articles of incorporation in connection with a convertible preferred stock venture capital financing.

22. See GoMPERS, supra note 14 , at 323 . The negative covenants are contained in a different closing document, the investors' rights agreement. Lee F. Benton, Robert V. Gunderson, Jr. \& Julie M. Robinson, Hi-Tech Corporation: Investors' Rights Agreement, in 1 Venture Capital and Public OfFERING Negotiation, supra note 7, at 9-1 to 9-40, sets out a form of investors' rights agreement with illustrative negative covenants.

23. GOMPERS, supra note 14, at 316; Anat Admati \& Paul Pfleiderer, Robust Financial Contracting and the Role of Venture Capitalists, 49 J. FIN. 371, 371 (1994).

24. Halloran et al., supra note 7, at 1-21 to 1-29.

25. See Alexander Ljunqvist \& Matthew Richardson, The Cash Flow, Return and Risk Characteristics of Private Equity 11 (Nat'l Bureau of Econ. Research, 
important determinant of its ability to raise capital for a new fund, early harvesting of a fund's investments will be beneficial. ${ }^{26}$ Venture capital funds exit successful investments by two general methods: taking the portfolio company public through an initial public offering of its stock (an "IPO"); or selling the portfolio company to another firm. The likelihood of exit by an IPO or a sale has differed over different periods. Between 1984 and 1990, 396 venture capital-backed firms went public, while 628 such firms were sold to other firms before going public. Between 1991 and 1996, the order reversed, with 1059 firms going public and 524 being sold. ${ }^{27}$ It is also common for the terms of a venture capital preferred stock investment to give the venture capital fund the right to require the portfolio company to redeem its stock. However, redemption does not operate as a viable exit mechanism because portfolio companies lack the funds to effect the redemption. ${ }^{28}$ Such put rights are better understood as a control device that can force the portfolio company to accommodate the fund's desire to exit by way of IPO or sale.

The fact that portfolio company investments are of limited duration rather than long term is critical to the operation of the venture capital market. ${ }^{29}$ The noncash contributions made by the venture capital fund to the portfolio company-management assistance, monitoring, and service as a reputational intermediary-share a significant economy of scope with its provision of capital. The portfolio company must evaluate the quality of the fund's proffered management assistance and monitoring, just as potential employees, suppliers, and customers must evaluate the fund's representations concerning the portfolio company's quality. Combining financial and nonfinancial contributions enhances the credibility of the information the venture capital fund proposes to provide the portfolio company and third parties. Put simply, the venture capital fund bonds the accuracy of its information with its investment.

The importance of the portfolio company investment's limited duration reflects the fact that the venture capital fund's noncash contributions have special value to early stage companies. As the portfolio company gains its own

Working Paper No. 9454, 2003) (showing that, on average, a fund invests 56.8\% of committed funds over the first three years, and $90 \%$ over the first six years).

26. Black \& Gilson, supra note 15, at 255-57; see STEVEN KAPLAN AND ANTOINETTE Schoar, Private Equity Returns: Persistance and CaPiTal Flows (working paper, 2003) (demonstrating that capital flows into private equity funds are strongly, positively, and significantly related to past performance) (on file with author). This need to display results may cause a GP without a performance record with prior funds to harvest investments earlier than would be optimal for the investors in order to establish a record sufficient to allow the raising of a new fund. See GOMPERS, supra note 14.

27. Black \& Gilson, supra note 15, at 248 tbl.1; Paul Gompers, Grandstanding in the Venture Capital Industry, 42 J. FIN. ECON. 133 (1996).

28. Black \& Gilson, supra note 15; GoMPERS, supra note 14. Kaplan \& Strömberg, supra note 14 , at 18 , report redemption rights in $84 \%$ of the financing rounds in their sample.

29. This discussion draws on Black \& Gilson, supra note 15. 
experience and develops its own reputation, the value of the venture capital fund's provision of those elements declines. By the time a portfolio company succeeds and the venture capital fund's exit from the investment is possible, the fund's noncash contributions can be more profitably invested in a new round of early stage companies. But because of the economies of scope between cash and noncash contributions, recycling the venture capital fund's noncash contributions also requires recycling its cash contributions. Exit from a fund's investments in successful portfolio companies thus serves to recycle its cash and, therefore, its associated noncash contributions from successful companies to early stage companies.

The risk associated with portfolio company investments is reflected in the variability of returns. While some investments return many multiples of the original investment, a survey of the performance of venture capital-backed companies, not limited to early stage technology companies and therefore presenting less uncertainty than the category of investments that concern us here, reports wide variation in returns. In the sample studied, fifty percent of the total return was provided by only $6.8 \%$ of the investments. Over a third of the investments resulted in partial or total loss. ${ }^{30}$

\section{THE ECONOMICS OF VENTURE CAPITAL CONTRACTING: THE SPECIAL PROBLEMS OF UNCERTAINTY, INFORMATION ASYMMETRY, AND AGENCY COSTS}

All financial contracts respond to three central problems: uncertainty, information asymmetry, and opportunism in the form of agency costs. The special character of venture capital contracting is shaped by the fact that investing in early stage, high technology companies presents these problems in an extreme form. ${ }^{31}$ Precisely because the portfolio company is at an early stage, uncertainty concerning future performance is magnified. Virtually all of the important decisions bearing on the company's success remain to be made, and most of the significant uncertainties concerning the outcome of the

30. Venture Economics, Exiting Venture CaPital InVESTMENTS (1988) (on file with author). This high variance is confirmed by a more recent econometric study. See John H. Cochrane, THE Risk and RETURn of VENTURE CAPITAL 2 (Nat'l Bureau of Econ. Research, Working Paper No. 8066, 2001) ("Venture capital investments are like options; they have a small chance of a huge pay off.").

31. George Triantis makes the apt point that bank financing of mature firms has functional parallels to venture capital contracting. For example, lines of credit that can be cancelled by the lender is a form of staged financing. George G. Triantis, Financial Contract Design in the World of Venture Capital, 68 U. CHI. L. REV, 305, 306 (2001). However, the combination of the portfolio company's negative cash flow, as well as the more extreme forms of uncertainty, information asymmetry, and agency, leads to the use of equity-like instruments and a level of control quite different from banking practice. This is consistent with the fact that "venture" funding in Europe by banks is characterized by late stage investments in low technology industries - circumstances in which these contracting problems are more muted. See MAYER ET AL., supra note 3, at 4. 
company's efforts remain unresolved. Additional uncertainty concerns the quality of the company's management, which takes on heightened importance because so large a portion of the portfolio company's value depends on management's future decisions. Finally, the technology base of the portfolio company's business exacerbates the general uncertainty by adding scientific uncertainty.

The same factors expand the information asymmetries between potential investors and entrepreneurs, as intentions and abilities are far less observable than actions already taken. Similarly, the fact that the portfolio company's technology involves cutting-edge science assures that there will be a substantial information asymmetry in favor of the entrepreneur even if the venture capital fund employs individuals with advanced scientific training.

Finally, the importance of future managerial decisions in an early stage company whose value depends almost entirely on future growth options, creates potentially large agency costs, 32 which are in turn amplified by the significant variance associated with an early stage, high technology company's expected returns. Because the entrepreneur's stake in a portfolio company with venture capital financing can be fairly characterized as an option, the entrepreneur's interests will sharply diverge from those of the venture capital investors, especially with respect to the risk level and duration of the investment. ${ }^{33}$

The organizational and contractual structure of the U.S. venture capital market responds to this trio of problems. The effectiveness of the response serves to make the venture capital market feasible. Absent a workable response, the extremity of uncertainty, information asymmetry, and agency problems likely would raise the cost of external capital to a point of market failure, leading to a similar collapse in the formation of early stage, high technology companies. Because of the link between firm size and innovation, ${ }^{34}$ institutional and contractual techniques thus have an important influence on the successful commercialization of cutting-edge science. Research and development by large companies with access to the public capital markets simply is not a substitute for the activities of early stage companies, financed through the private equity market and dependent on contractual solutions to the problems of uncertainty, information asymmetry, and agency costs. ${ }^{35}$

32. GOMPERS, supra note 14, at 317.

33. For a discussion on the characterization of a corporate stock as an option, see Fischer Black \& Myron Scholes, The Pricing of Options and Corporate Liabilities, $81 \mathrm{~J}$. POL. ECON. 637 (1973); Stewart C. Myers, Determinants of Corporate Borrowing, 5 J. FIN. ECON. 147 (1977). The application of option pricing analysis to transactional and contractual structuring is developed in RONALD J. GILSON \& BERNARD S. BLACK, THE LAW AND FINANCE OF CORPORATE ACQUISITIONS 231-57 (2d ed. 1995).

34. See Kortum \& Lerner, supra note 1.

35. See Joseph Bankman \& Ronald J. Gilson, Why Start-Ups?, 51 StAN. L. REV. 289 
The organizational and contractual techniques observed in the venture capital market reflect three basic characteristics. First, very high power incentives for all participants-investors, GPs, and entrepreneurs-are coupled with very intense monitoring. ${ }^{36}$ Second, the organizational and contractual structure reflects the use of both explicit and implicit contracts. Thus, the governance structure of both the portfolio company and the venture capital fund is composed of market as well as formal aspects. Third, a pivotal aspect of this mix of formal and market governance, especially repeat play and reputation mechanisms, is that the two contracting nodes which comprise the venture capital market - the venture capital fund limited partnership agreement and the portfolio company investment contract-are determined simultaneously. As we will see, this braiding of the two relationships facilitates the resolution of problems internal to each.

This Part shows how multiple forms of incentive and monitoring techniques, including contractual, control, and market mechanisms, operate in connection with each contracting node to resolve the problems of uncertainty, information asymmetry, and agency associated with early stage, high technology financing. We consider first the venture capital fund-portfolio company contract and then turn to the investor-venture capital fund limited partnership agreement. Finally, we consider the importance of the braiding of these two contracts.

\section{A. The Venture Capital Fund-Portfolio Company Contract}

Five organizational and contractual techniques discussed in Part I-staged financing, allocation of elements of control, form of compensation, the role of exit, and reliance on implicit contracts-respond to the problems posed by financial contracting in the face of extreme forms of uncertainty, information asymmetry, and agency costs.

\section{Staged financing.}

By giving the investor a valuable option to abandon, the staged financing structure discussed in Part I responds directly to the uncertainty associated with contracting for early stage, high technology investments. The milestones in the business plan are keyed to events that, when they occur, reveal important information and thereby reduce the uncertainty associated with the project's ultimate success. Thus, a first milestone may be the creation of an operating

(1999) (discussing the advantages of start-up form).

36. This is consistent with Milgrom \& Roberts's "monitoring intensity principle," which predicts that, because intense incentives give rise not only to incentives to perform, but also to incentives to cheat, intense incentives require a significant investment in monitoring. Paul Milgrom \& John Roberts, ECONomics, Organization \& MANAGEMENT 206-47 (1992). 
prototype, which eliminates uncertainty about the portfolio company's ability to reduce its science to a commercial product. The decision about additional investment is then made only after the passage of time and performance has replaced projection with fact. The result is to reduce the uncertainty associated with the funding of further rounds of investment. ${ }^{37}$

Without more, however, staged financing does not increase the expected value of the portfolio company's project. To be sure, the investor receives an option to abandon, but the value of that option to the recipient is exactly balanced by the cost of the option to its writer, the entrepreneur. Absent an unrealistic assumption about investor risk aversion, merely shifting exogenous uncertainty from the investor to the entrepreneur does not create value. ${ }^{38}$ For this to occur, staged financing must accomplish something more.

The first respect in which staged financing creates, rather than merely transfers, value is its reduction of the agency problems associated with the entrepreneur's management of the portfolio company's operation. Staged financing aligns the interests of the venture capital fund and the entrepreneur by creating a substantial performance incentive. If the portfolio company does not meet the milestone whose completion was funded in the initial round of financing, the venture capital fund has the power to shut the project down by declining to fund the project's next round. ${ }^{39}$ Even if the venture capital fund chooses to continue the portfolio company's project by providing another round of financing, a performance penalty still can be imposed by assigning the portfolio company a lower value in the new round. To be sure, the portfolio company may seek financing from other sources if the existing investors decline to go forward, or are willing to go forward only at an unfavorable price, but the overall contractual structure significantly reduces the availability of a market alternative.

First, potential investors know they are being solicited only because investors in the prior round are dissatisfied with the portfolio company's performance. Second, the investors' rights agreement gives the venture capital fund a right of first refusal with respect to future financing that serves as a substantial deterrent to potential alternative investors. Such an investor will be

37. Brealey \& Myers provide an accessible discussion of how to value the option to abandon. Richard A. Brealey \& SteWART C. MYers, Principles of CORPORATE FinanCE, 622-25 (6th ed. 2000).

38. Indeed, the more realistic assumption is that the entrepreneur is risk averse with respect to the success of the portfolio company since, unlike the venture capital fund, she will not hold a diversified portfolio of financial or human capital.

39. The venture capital fund's noncapital contributions are also effectively staged. If the portfolio company has not performed satisfactorily, the GP can decline to make or receive telephone calls from the portfolio company or its suppliers, customers, or prospective employees. See Black \& Gilson, supra note 15, at 254. Gompers, supra note 17, at 1462, likens this incentive to that provided by the role of debt in a leveraged buyout. The need for additional funds provides a portfolio company the same "hard" constraint provided by the need to pay back debt in a leveraged buyout. 
reluctant to make the outlay to acquire the information necessary for deciding whether to make an investment knowing that that investment will be significantly reduced if the terms negotiated turn out to be attractive, since the existing investors will have the right to take part or all of the transaction for themselves. The result is a serious winner's curse problem. The potential investor can anticipate that if the price negotiated is attractive, the existing investors will opt to make the investment themselves. Thus, the potential investor knows that it will be allowed to make the investment only if the existing investors, who have better information about the project, believe that the investment is unattractive.

Staged financing also reduces agency costs by shifting the decision whether to continue the project from the entrepreneur to the venture capital fund. Because of the option-like character of the entrepreneur's interest in the portfolio company, she will go forward with the project under conditions that favor her and disfavor the venture capital fund. Shifting this decision to the venture capital fund reduces this source of agency cost.

The incentive created by staged financing in turn operates to reduce uncertainty in a manner that creates value, rather than merely shifting it from the investor to the entrepreneur. While staged financing only shifts risk with respect to exogenous uncertainty - that is, uncertainty which is outside the parties' capacity to influence-it actually can serve to reduce a different kind of uncertainty. Some uncertainty associated with the success of the portfolio company's project is endogenous: It can be influenced by the entrepreneur's actions. Put differently, the likelihood of the portfolio company's success is in part a function of the effort expended. By increasing the incentives to expend effort, staged financing reduces this element of uncertainty.

That brings us to the effect of staged financing on the information asymmetry between the venture capital fund and the entrepreneur. Staged financing serves to bridge the information gap in two important ways. First, every incentive has an information-related flip side that responds to adverse selection problems. In deciding which portfolio companies to finance, the venture capital fund has to distinguish between good and bad entrepreneurs under circumstances in which an entrepreneur has better information about her own skills than does the investor. Because the incentive created by staged financing is more valuable to a good entrepreneur than a bad one, an entrepreneur's willingness to accept an intense incentive is a signal of the entrepreneur's difficult-to-observe skills. The signal is particularly important for early stage and high technology portfolio companies because the absence of a performance history and the technical nature of the projects makes the entrepreneur's skills particularly difficult to observe. 40

40. Conceptually, the signal will result in a separating equilibrium, in which only high quality entrepreneurs will accept the incentive, when the low quality entrepreneurs' alternatives are more valuable to a low quality entrepreneur than the incentive contract. See 
Staged financing reduces information asymmetry in a second way by its impact on the credibility of the projections contained in the entrepreneur's business plan. These projections are critical to valuing the portfolio company and therefore pricing the venture capital fund's investment. Yet, the entrepreneur obviously has better information concerning the accuracy of the business plan's projections of timing, costs, and likelihood of success. Without more, the entrepreneur has an obvious incentive to overstate the project's prospects. By accepting a contractual structure that imposes significant penalties if the entrepreneur fails to meets specified milestones based on the business plan's projections - the venture capital fund's option to abandon then becomes exercisable - the entrepreneur makes those projections credible.

At this point, it is helpful to note a more general contracting problem associated with the allocation of discretion between parties to an agreement. Discretion creates the potential for the party possessing it to impose agency costs. Staged financing, like other organizational and contractual techniques we will consider, responds to agency problems that result from entrepreneur discretion by shifting that discretion to the venture capital fund. However, this technique has a built-in limitation, which we might call the principle of the conservation of discretion. Without more, shifting discretion from the entrepreneur to the fund does not eliminate the potential for agency costs; it merely shifts the chance to act opportunistically to the fund. For example, staged financing coupled with a right of first refusal made potent by high information costs allows the venture capital fund to behave opportunistically in negotiating the price of a second round of financing. The fund is in a position to exploit its monopsony power by reducing the value assigned to the portfolio company even though it has met its projections. ${ }^{41}$ In such settings, the goal is to shift discretion to that party whose misuse of it can be most easily constrained. ${ }^{42}$ As will appear, misuse of the discretion shifted to the venture capital fund is policed by market forces in the venture capital market, whose functioning is crucial to the feasibility of the entire organizational and contractual structure.

\section{Control.}

The venture capital fund-portfolio company contract stands the BerleMeans problem on its head. Instead of investors having disproportionately

GOMPERS, supra note 14; Edward Lazear, Salaries and Piece-Rates, 59 J. BUS. 405 (1986).

41. Black \& Gilson, supra note 15, at 261-63.

42. In their discussion of the efficient allocation of property rights in innovation between the innovation and the investor, Phillipe Aghion and Jean Tirole do not consider the problem of dual-sided moral hazard considered in the text. Rather, they argue that ownership should be allocated to investor or innovator based on size of marginal contribution. Phillipe Aghion \& Jean Tirole, The Management of Innovation, 109 Q.J. ECON. 1185 (1994). 
more equity than control as in public corporations, the venture capital fund has disproportionately more control than equity. Like staged financing, this allocation of control responds to the problems of uncertainty, information asymmetry, and agency associated with early stage, high technology investments.

Extreme uncertainty concerning the course and outcome of the project stage being financed creates discretion. The presence of uncertainty means that the financing contract is necessarily incomplete; an explicit stage-contingent contract that specifies what action should be taken in response to all possible events cannot be written. Thus, the contractual structure must deal with uncertainty by means of a governance structure: creating a process that will determine the response to an unexpected event. The particular allocation of discretion between the fund and the portfolio company reflects the influence of concerns over both agency and information asymmetry.

Two types of control are allocated to the venture capital fund as a response to agency and information asymmetry problems. First, as we have seen, staged financing allocates an important periodic lever of control to the venture capital fund. By reserving to itself the decision of whether to fund the portfolio company's next milestone, the venture capital fund takes control over the continuation decision. This power, in turn, gives the venture capital fund the incentive to make the investment in monitoring necessary to evaluate the portfolio company's overall performance over the initial funding period. In the absence of the power to act in response to what it discovers, the venture capital fund would have no reason to expend time and resources in the kind of monitoring necessary to balance the intense incentives created to align the two parties' interests.

Second, giving the venture capital fund disproportionate representation or even control of the portfolio company's board of directors, and the restriction of the entrepreneur's discretion through the use of negative covenants, gives the fund interim control-the power to act to reduce agency costs in the period between financing rounds. In its most extreme form, the venture capital fund's interim control carries with it the power to replace the entrepreneur as the portfolio company's chief executive officer. As with the allocation of periodic control, the allocation of interim control gives the venture capital fund the incentive to monitor the portfolio company's performance during the course of reaching a funding milestone, and in response to the unexpected events generated by pervasive uncertainty. The discretion unavoidably given to the portfolio company's day-to-day managers by the occurrence of unexpected events is policed by the disproportionate control and resulting monitoring activity allocated to the venture capital fund.

The periodic and interim monitoring encouraged by the disproportionate allocation of control to the venture capital fund also serves to reduce the last of the contracting problems-information asymmetry between the venture capital fund and the entrepreneur. The balance of information between the parties is 
not static as the portfolio company moves forward on its business plan. Ongoing learning by the entrepreneur increases the information disparity and therefore the entrepreneur's discretion, which in turn increases agency costs. Ongoing monitoring by the venture capital fund, made possible by the disproportionate allocation of control, balances that influence.

Finally, as with staged financing, the allocation of control serves to reduce information asymmetry by providing the entrepreneur the opportunity to signal her type. Giving the venture capital fund the power to terminate the entrepreneur in the event of poor performance gives the entrepreneur a powerful incentive to perform. The flip side of this incentive is a signal. By demonstrating her willingness to subject herself to this penalty for poor performance, the entrepreneur credibly provides information to the venture capital fund about her confidence in her own skills. ${ }^{43}$

\section{Compensation.}

The structure of the entrepreneur's compensation responds primarily to agency costs and information asymmetry problems. Perhaps more starkly than any other organizational or contractual technique, the portfolio company's compensation structure creates extremely high-powered performance incentives that serve to align the incentives of the portfolio company management and the venture capital fund. In essence, the overwhelming percentage of management's compensation is dependent on the portfolio company's success. Low salaries are offset by the potential for a large increase in the value of the entrepreneur's stock ownership, and by the award of stock options to other management members. The performance incentive is further heightened by the practice of requiring the entrepreneur and other members of management to accept the imposition of a staged vesting requirement on some or all of their stock or stock options. The vesting requirement gives the portfolio company the right to purchase a portion of the entrepreneur's or other management's stock, at a favorable price, if employment terminates prior to a series of specified dates. It also restricts exercise of options until after the manager has completed a series of employment anniversaries, following each of which an additional number of options both are exercisable and no longer subject to forfeiture if employment terminates. 44

43. See Thomas Hellmann, The Allocation of Control Rights in Venture Capital Contracts, 29 RAND J. ECON. 57 (1998) (finding that, under the optimal contract, entrepreneurs commonly relinquish control to venture capitalists by accepting vesting of their stock and modest severance packages). Kaplan and Strömberg, supra note 14, at 23, report that $55 \%$ of early stage financings contained entrepreneur vesting requirements.

44. Lee F. Benton, Robert V. Gunderson, Jr. \& Julie M. Robinson, Portfolio Company Investments: Hi-Tech Corporation, in VENTURE CAPITAL AND PUBLIC OFFERING Negotiation, supra note 7, at 6-16 to 6-17; Sahlman, supra note 7, at 508 . 
While aligning the interests of the venture capital fund and entrepreneur in some circumstances, the intensity of these incentives can also lead to agency costs in others. In particular, the option-like characteristics of the portfolio company's compensation structure can lead the entrepreneur to increase the risk associated with the portfolio company's future returns, because the venture capital fund will bear a disproportionate share of the increased downside but share only proportionately in the upside. Thus, the intensity of the performance incentives created by the compensation structure gives rise to a corresponding incentive for the venture capital fund to monitor the portfolio company's performance. This monitoring, together with the signaling properties of the entrepreneur's willingness to accept such powerful incentives, also serves to reduce information asymmetries.

4. Exit.

Another powerful incentive is created for the entrepreneur by the terms of the disproportionate allocation of control to the venture capital fund. On the plausible assumption that the transfer of control to the venture capital is costly to the entrepreneur, ${ }^{45}$ the control structure created by the venture capital fund's investment gives the entrepreneur a valuable call option on control. ${ }^{46}$ In effect, the venture capital fund and the entrepreneur enter into a combination explicit and implicit contract that returns to the entrepreneur the disproportionate control transferred to the venture capital fund if the portfolio company is successful. ${ }^{47}$ The explicit portion of the contract is reflected in the terms of the convertible preferred stock that provide the venture capital fund its disproportionate board representation and in the investors' rights agreement's negative covenants that require venture capital fund approval of important operating decisions. Both documents typically provide for the termination of these levers of control upon the completion of an IPO of a specified size and at a specified price. The terms of the preferred stock almost universally require conversion into common stock, with the resulting disappearance of special

45. A private value for control is a standard feature in models that seek to explain the incentive function of capital structure. See, e.g., Sanford J. Grossman \& Oliver D. Hart, One Share-One Vote and the Market for Corporate Control, 20 J. FIN. ECon. 175 (1988) (analyzing the optimality of the one share-one vote rule for allocating control); Milton Harris \& Artur Raviv, Corporate Governance: Voting Rights and Majority Rules, 20 J. FIN. ECoN. 203 (1988) (arguing that simple majority voting rule and one share-one vote are the optimal rules for electing controlling management); Bengt R. Holstrom \& Jean Tirole, The Theory of the Firm, in HANDBOOK OF INDUSTRIAL ORGANIZATION 61, 79-86 (Richard Schmalensee \& Robert D. Willig eds., 1989) (discussing various theories of capital structure based on incentive reasoning, signaling, and control rights).

46. Black \& Gilson, supra note 15 , develop the concept of an implicit contract giving the entrepreneur a call option on control in venture capital contracts.

47. Some contracts also provide for automatic conversion when the portfolio company meets specified profits or, less frequently, sales targets. GOMPERS, supra note 14, at 329 . 
board representation, on a public offering. The negative covenants in investors' rights agreements also typically expire on an IPO. 48

The implicit portion of the contract operationalizes the definition of success that makes the entrepreneur's call option on control exercisable. By triggering automatic conversion on an IPO, determination of the measure of success is delegated to independent investment bankers who are in the business of identifying venture capital-backed companies successful enough to be taken public, ${ }^{49}$ and whose own incentives make their ex post determination of success credible ex ante. As we will see in the next section, this structure also allocates to the market enforcement of the venture capital fund's implicit promise to agree to an IPO when one is available to the portfolio company and the entrepreneur exercises her call option on control by requesting one.

\section{Reliance on implicit contract: The role of the reputation market.}

Crucial elements of the organizational and contractual techniques that respond to uncertainty, information asymmetry, and agency costs in the venture capital fund-portfolio company relationship, have at their core the transfer of discretion from the entrepreneur to the venture capital fund. Staged financing, by giving the venture capital fund an option to abandon, transfers the continuation decision from the entrepreneur to the fund. Disproportionate board control by the venture capital fund, including the power to dismiss the entrepreneur herself, also transfers to the fund the capacity to interfere in the portfolio company's day-to-day business. As a result, the effectiveness of these techniques is subject to the conservation of discretion principle. Reducing the agency costs of the entrepreneur's discretion by transferring it to the venture capital fund also transfers to the venture capitalist the potential for agency costs-i.e., the opportunity to use that discretion opportunistically against the entrepreneur.

For example, giving the venture capital fund an option to abandon gives the venture capital fund an incentive to monitor, gives the entrepreneur an

48. The venture capital fund's ownership percentage, and therefore control, is further diluted both by the number of new shares sold to the public in the IPO, and by the number of shares sold by the venture capital fund either in the offering or in the period following the offering. Black \& Gilson, supra note 15, at 260-61.

49. See Christopher B. Barry, Chris J. Muscarella, John W. Peavy III \& Michael R. Vetsuypens, The Role of Venture Capitalists in the Creation of Public Companies: Evidence from the Going-Public Process, 27 J. FIN. ECON. 447 (1990) (noting that intensive monitoring services provided by venture capitalists lowers underpricing for venture-backed IPOs); Alon Brav \& Paul A. Gompers, Myth or Reality? The Long-Run Underperformance of Initial Public Offerings: Evidence from Venture and Nonventure Capital-Backed Companies, 52 J. FIN. 1791 (1997) (identifying quality of underwriter as one factor for higher returns of venture-backed IPOs as compared to nonventure-backed IPOs); William L. Megginson \& Kathleen A. Weiss, Venture Capitalist Certification in Initial Public Offerings, 46 J. FIN. 879 (1991) (arguing that certification by venture capitalists partially substitutes and complements certification by investment bankers). 
incentive to perform, and reduces agency costs by shifting the continuation decision to the venture capitalist. But when coupled with the venture capital fund's right of first refusal, this transfer of discretion also creates agency costs on the part of the venture capital fund. What prevents the venture capital fund from opportunistically offering to provide the financing necessary for the portfolio company's next stage only at an unfairly low price, relying on a right of first refusal to restrict the entrepreneur's access to other sources of funding? ${ }^{50}$ Similarly, the transfer of disproportionate control to the venture capital fund creates the potential for opportunism by the fund. To align incentives, the entrepreneur's returns from the portfolio company's project take the form of appreciation in the value of her portfolio company stock and stock options. However, the venture capital fund's power to terminate the entrepreneur, coupled with the vesting requirements that both give the portfolio company a favorably priced option to purchase the entrepreneur's stock and cancel all unvested options upon her termination, gives the venture capital fund the discretion to behave opportunistically. What prevents the venture capital fund from unfairly terminating the entrepreneur so as to secure for itself the returns that had been promised to the entrepreneur?

The conservation of discretion principle counsels that discretion be vested in the party whose behavior is more easily policed. In the context of the venture capital fund-portfolio company relationship, the presence of an effective reputation market with respect to the GP's characteristics provides the policing that supports the transfer of discretion to the venture capital fund.

For a reputation market to operate, three attributes must be present. First, the party whose discretion will be policed by the market must anticipate repeated future transactions. Second, participants must have shared expectations of what constitutes appropriate behavior by the party to whom discretion has been transferred. Finally, those who will deal with the advantaged party in the future must be able to observe whether that party's behavior in past dealings conforms to shared expectations. ${ }^{51}$ All three of these attributes appear present in the venture capital market.

It is unlikely that a GP will have future dealings with the same entrepreneur. ${ }^{52}$ However, as we have seen, the GP will anticipate raising successor venture capital funds, which in turn will require future dealings with different entrepreneurs in connection with the investing the new funds' capital. The requirements of shared expectations of proper conduct, and the

50. See supra text accompanying notes $39-40$.

51. D. Gordon Smith, Venture Capital Contracting in the Information Age, 2 J. SMaLL \& EMERG. BUS. L. 133 (1998), examines the information characteristics of the reputation market for venture capitalists.

52. It is not, however, impossible. Both successful and unsuccessful first round entrepreneurs may found a new start-up company in need of venture capital financing. See annalee Saxenian, Regional advantage: Culture and Competition IN Silicon VALLEY AND ROUTE 128, at 38-39 (1994). 
observability of a GP's satisfaction of those expectations, also appear to be met in the venture capital market. The community of venture capital funds is relatively concentrated ${ }^{53}$ and remarkably localized. For example, the offices of a significant percentage of U.S. venture capital funds are found along a short strip of Sand Hill Road in Silicon Valley. ${ }^{54}$ Moreover, venture capital funds typically concentrate their investments in portfolio companies geographically proximate to the fund's office. ${ }^{55}$ This geographical concentration of providers and users of venture capital facilitates satisfaction of the informational element of the structure of a reputation model. Saxenian notes that geographical proximity has fostered in Silicon Valley extremely efficient informal transfers of information concerning the performance of GPs and entrepreneurs. 56 Credible accounts of opportunistic behavior by particular GPs can be expected to circulate quickly among members of the entrepreneur community, who must select a GP with whom to deal, and among members of the GP community, who must compete among themselves for the opportunity to invest in the most promising portfolio companies and therefore have an interest in noting and transmitting to the entrepreneur community instances of misbehavior by a rival.

\section{B. The Investor-Venture Capital Fund Contract}

In this Part, we turn to the investor-venture capital fund contract. How do the organizational and contractual techniques discussed in Part I-virtually complete control vested in the GP, highly incentivized compensation, mandatory distribution of realized investments, and mandatory liquidation after

53. See David J. Ben Daniel, Jesse E. Rees \& Michael D'Angelo, Concentration AND CONSER VATISM IN THE VENTURE CAPITAL INDUSTRY (Working Paper, 1998) (on file with author). In 1987, the top five percent of firms acting as venture capital fund GPs controlled $20 \%$ of venture capital raised. The figure rose to $37 \%$ in 1992 , and to $44 \%$ in 1997 .

54. SAXENIAN, supra note 52, at 39-40. (Over the period 1996-1999, $41 \%$ of all U.S. venture capital investments were made to portfolio companies located in California. Kaplan \& Strömberg, supra note 14 , at 10 )

55. Lerner, supra note 16 , reports that venture capital providers located within five miles of a portfolio company are twice as likely to have a board representative as providers located more than 500 miles from a portfolio company. See Olav SORENSON \& TOBY E. Stuart, Syndication Networks and the Spatial Distribution of Venture Capital INVESTMENTS (Soc. Sci. Research Network Elec. Paper Collection, Working Paper, 1999) (demonstrating the geographic and industry-localization of venture capital investments), available at $\mathrm{http}: / /$ papers.ssrn.com/sol3/papers.cfm?abstract_id=220451.

56. SAXENIAN, supra note 52. 
a fixed term ${ }^{57}$-respond to the problems of financial contracting in the face of extreme forms of uncertainty, information asymmetry, and agency costs? ${ }^{58}$

\section{Control.}

Organizing the venture capital fund as a limited partnership serves to vest virtually complete control in the GP. Short of participation in largely inconsequential advisory committees and the right, typically restricted by the limited partnership agreement, to replace the GP, the legal rules governing limited partnerships prevent investors from exercising control over the central elements of the venture capital fund's business. Most important, the investors are prohibited from insisting on an approval right of the GP's investment decisions. Thus, the venture capital fund's formal governance structure presents an extreme version of the Berle-Means problem of the separation of ownership and control: The GP receives control grossly disproportionate to either its one percent capital contribution or its twenty percent carried interest.

The efficiency explanation for the allocation of control to the GP reflects in the first instance the extreme uncertainty and information asymmetry associated with investing in early stage, high technology portfolio companies. By investing through a financial intermediary, investors secure the benefit of the GP's skill and experience, which help to reduce the level of uncertainty and information asymmetry that must be addressed in the contract governing a portfolio company's investment. However, securing the benefit of the GP's expertise comes at a cost: The GP must be given the discretion necessary to exercise its skills and experience on the investors' behalf. And consistent with the principle of the conservation of discretion, the allocation of control to the GP creates the potential for agency costs that must be addressed by other elements of the venture capital fund's organizational and contractual structure.

57. A form of staged financing also appears in the investor-venture capital fund contract. The limited partners retain the right to withdraw from completing their promised capital commitments, in effect staging the commitment of capital to the venture capital fund. Sahlman, supra note 7, at 493-94. Because of the penalties associated with an investor failing to make its contribution following a capital call, the investor's option to abandon is of little value compared to the fund's option to abandon written by the portfolio company.

58. Empirical evidence of the value of the organizational and contractual structure is beginning to emerge. Christopher B. Barry \& L. Adel Turki, Initial Public Offerings by Development Stage Companies, 2 J. SMALl \& EMERG. Bus. L. 101 (1998), report that development stage companies that use an IPO as a substitute for venture capital on average experience poor long-term performance. In contrast, the portfolios of venture capital funds on average earn favorable returns. Ronald J. Gilson, Understanding the Choice Between Public and Private Equity Financing of Early Stage Companies: A Comment on Barry and Turki, 2 J. SMALl \& EMERG. Bus. L. 123 (1998), suggests that the different posttransaction governance structures associated with the two forms of development stage financing could explain the different levels of performance. 


\section{Compensation.}

The GP's compensation structure is the front line response to the potential for agency costs resulting from allocating to the GP the control necessary to apply its skill and expertise on behalf of the investors. As discussed in Part I, the bulk of the GP's compensation comes in the form of a carried interest (twenty percent of the venture capital fund's ultimate profits is a common figure) distributed to the general partner when realized profits are distributed to the limited partners. Thus, the compensation structure aligns the GP's interests in the fund's success with those of the investors: The GP earns returns that are proportional to those earned by the investors. However, other agency problems appear in the details of the carried interest. For example, suppose that the first investment realized by the venture capital fund yields a $\$ 1$ million profit after a return to the investors of their $\$ 1$ million investment. The GP's share of the profit is $\$ 200,000$. Now suppose that the next investment realized loses $\$ 500,000$, leaving cumulative profits from the two investments of $\$ 500,000$. If the GP keeps all of its first $\$ 200,000$ distribution, then it ends up having received not twenty percent of the venture capital fund's profits from the two investments, but forty percent $(\$ 200,000 / \$ 500,000)$. This would give the GP an incentive to realize profitable investments before unprofitable investments, even if that meant realizing the profitable investments prematurely. Various formulations of what are called "claw back" provisions respond to the potential agency cost growing out of this element of uncertainty by either delaying the GP's distribution, or holding back some portion of it, so that the GP's carried interest can be calculated in total after performance is known. ${ }^{59}$

\section{Mandatory distributions and fixed term.}

While aligning the interests of the GP and the investors, the intensity of the GP's compensation incentive in turn creates a different agency cost. The GP's carried interest has option-like characteristics, which may cause it to prefer investments of greater risk than the investors. This is especially true with respect to the fund's later investments if the early ones have done poorly. In that circumstance, the GP actually may be best served by making negative net present value investments if the investments are sufficiently risky. The same problem arises with respect to operating decisions that concern a portfolio company that is doing poorly. Then the option-like character of the GP's carried interest may align its interests more closely with those of the entrepreneur, whose compensation under the venture capital fund-portfolio company also has option-like characteristics. In that circumstance, both the GP and the entrepreneur may prefer a riskier operating strategy than would best serve investors.

59. See Halloran et al., supra note 7, at 1-81. 
The venture capital fund's fixed term, together with the operation of the reputation market, responds to this agency cost problem. The fund's fixed term assures that at some point the market will measure the GP's performance, making readily observable the extent to which the GP's investment decisions favored increased risk over expected return. A GP's track record, as revealed by the performance of its previous funds, is the GP's principal tool for persuading investors to invest in successor funds. Thus, the limited partnership's fixed term assures that opportunistic behavior by the GP with respect to either venture capital fund investment decisions or portfolio company operating decisions will be punished through the reputation market when it seeks to raise the successor funds that justify the GP's investment in skill and experience in the first place. 60 The expectation of such a settling up helps support the use of intense compensation incentives by constraining optioninduced GP opportunism.

Mandatory distribution of the proceeds from realized investments and the venture capital fund's fixed term also respond to a different variety of agency costs resulting from the allocation of control to the GP. Because the GP receives a fixed fee, typically in the range of $2.0 \%$ to $2.5 \%$ of committed capital, the GP would have an incentive to keep capital within the fund for as long as possible. If given the opportunity, the GP would simply reinvest the proceeds of realized investments. Moreover, that opportunity would make it unnecessary for GPs to raise successor funds, the anticipation of which allows the reputation market to police GP performance. Mandatory distribution of realized proceeds and a fixed term respond to this potential free cash flow problem. Both devices require that the GP allow the investors to measure its performance against alternatives available in the market before it can continue managing the investors' money. In this respect, mandatory distributions operate like debt in a post-leveraged buyout company: Profits must first be returned to investors before the company can seek to reclaim them by persuading investors to make a new investment. The fixed term operates like a contractually imposed takeover by forcing the GP to allow the investors to choose whether the GP should continue to manage their funds. The organizational and contractual structure assures that a time will come when market price serves as the measure of the GP's performance. ${ }^{61}$

60. See KAPLAN \& SCHOAR, supra note 26 (explaining that a VC with a better (worse) track record is more (less) likely to raise a follow-on fund).

61. The absence of these characteristics helps explain why closed end investment companies, like American Research and Development Company, the first venture capital fund formed in 1946 before the limited partnership structure was invented, never caught on. See Paul A. Gompers, The Rise and Fall of Venture Capital, 23 Bus. \& ECON. Hist. 1 (1994). 


\section{Braiding of the Venture Capital Fund-Portfolio Company and the Investor-Venture Capital Fund Contracts}

A final means by which the organizational and contractual structure of the venture capital-portfolio company and investor-venture capital fund contracts responds to the contracting problems posed by extreme uncertainty, information asymmetry, and agency costs is through the braiding of the two contracts. By braiding I mean the fact that the structure of the two contracts are intertwined, each operating to provide an implicit term that supports the other, and thereby increasing the contractual efficiency of both. This characteristic is particularly apparent in two areas: the role of exit and the reputation market.

\section{The braiding of exit.}

As we have seen, the obligation of exit from each of the two contracts comprising the venture capital market-the fixed term of the investor-venture capital fund contract, and the incentive to realize and then distribute the proceeds of the investment that is the subject of the venture capital fundportfolio company contract-responds to contracting problems presented by each of the relationships. Here the focus is on how these two functions of exit complement each other. As we saw in Part I, by the time a portfolio company succeeds, the venture capital fund's noncash contributions to a portfolio company can be more profitably invested in a new round of early stage companies. But because economies of scope link the provision of cash and noncash contributions, recycling the noncash contributions requires the venture capital fund to exit: to recycle its cash contribution from successful portfolio companies to new early stage companies. ${ }^{62}$ Moreover, the venture capital fund's exit provides the means to give the entrepreneur an important performance incentive: a call option on control, the exercise of which is implemented by the venture capital fund's realization of its investment in the portfolio company by means of an IPO.

In turn, the recycling of investments from successful portfolio companies to new early stage companies supports the investor-venture capital fund contract. Realizing portfolio company investments provides a performance measure that lets investors evaluate the GP's skill and honesty, and reallocate their funds to the GPs with the most successful performance. And by providing the GP's primary tool for persuading investors to provide capital for successor funds, exit supports the core of the incentive structure that aligns the interests of investors and the GP.

In sum, the braiding of the role of exit in the investor-venture capital fund contract and the venture capital fund-portfolio company contract increases the efficiency of both contracts.

62. Black \& Gilson, supra note 15 , at 254-55. 


\section{The braiding of the reputation market.}

The venture capital fund-portfolio company contract responds to a number of problems by shifting important elements of control to the venture capital fund. The venture capital fund's option to abandon resulting from staged financing, its board representation and even control, and its power to replace the entrepreneur, combine to reduce uncertainty and agency costs in two ways. First, it provides the entrepreneur powerful performance incentives, including a call option to regain control. Second, it provides the venture capital fund with the means, and therefore the incentive, to monitor. In turn, the entrepreneur's willingness to transfer control, and to accept so heavily incentivized a contract structure, reduces the information asymmetry by signaling the entrepreneur's type. However, each of these transfers of discretion from the entrepreneur to the venture capital fund carries with it the potential for opportunistic behavior by the fund. The entrepreneur is at risk in connection with negotiations over the terms of the next round financing, in connection with the venture capital fund's exercise of control through board influence and its power to replace the entrepreneur, and in connection with the fund's ability not to honor the implicit call option on control it has written. The efficiency of the venture capital fundportfolio company contract therefore requires a credible constraint to prevent the venture capital fund from misusing its transferred discretion.

The braiding of the venture capital fund-portfolio company contract with the investor-venture capital fund contract supports a reputation market that constrains opportunistic behavior by the venture capital fund. Because the fund is unlikely to engage in repeated deals with any particular entrepreneur, the reputation market constraint instead grows out of the investor-venture capital fund contract. Because the GP needs to raise successor funds, it will have to make investments in new portfolio companies run by other entrepreneurs. If a GP behaves opportunistically toward entrepreneurs in connection with previous portfolio company investments, it will lose access to the best new investments. This, in turn, will make raising successor funds more difficult. The impact of the GP's behavior toward current portfolio companies on the success of its future fund raising efforts serves to police the venture capital fund's exercise of the discretion transferred to it in the venture capital fund-portfolio company contract. In turn, the investor-venture capital fund contract's support of the transfer of discretion to the fund by the venture capital fund-portfolio company contract helps reduce the contracting problems in the portfolio company contract and therefore results in higher returns to investors. This encourages investors to reinvest in the GP's successor funds. Again, the interaction between the two contracts supports the efficiency of each. 


\section{The EngINEERING Problem}

The canvas of the U.S. venture capital contracting structure in Parts I and II brings me to the engineering problem. The central lesson to be learned from the U.S. venture capital market is that it is overwhelmingly the product of private ordering - an extremely effective contracting structure that covers the entire venture capital cycle, from initial investment in the VC fund, to the VC fund's investment in a portfolio company, to the exit from the portfolio investment to allow the VC fund's cash and noncash investment to be recycled. ${ }^{63}$ Can this model be replicated elsewhere? Who will be the engineer? Can the government act as the engineer in creating a system that is driven by private ordering?

The discussion must begin with a caveat. I have in mind a relatively restricted engineering problem. Any form of effective capital market requires a range of social, legal, and economic institutions, such as honest courts, an effective auditing profession, and informational and reputational transparency. ${ }^{64}$ Because of the braided aspect of venture capital contracting, the whole spectrum of foundational institutions is important to the venture capital market. For present purposes, I will assume away the more difficult problem of how to engineer the foundational structure of capital markets, focusing instead on the more limited issue that is plainly of interest to many nations and multinational entities like the EU and OECD: how to engineer a venture capital market.

At this level, developing a venture capital market confronts a difficult coordination problem that I will call simultaneity. A venture capital market requires the simultaneous availability of three factors, the provision of any one of which is contingent on the availability of the other two. A venture capital market requires (1) entrepreneurs, (2) investors with the funds and the taste for high-risk, high-return investments, and (3) (as the discussion of U.S. venture capital contracting illustrates) a specialized financial intermediary to serve as the nexus of a set of sophisticated contracts.

The nature of the simultaneity problem can be illustrated by a more familiar example: the development of the U.S. credit card industry. For a market for credit cards to develop, three factors were necessary. The industry required consumers who would carry credit cards, merchants who would accept the cards, and a network of card issuers to provide the cards and the back office services necessary for their use. If any two of the three elements were available, the third would be forthcoming. For example, if one observes consumers who want credit cards and a network that will provide the cards and the system, merchants will want to accept the cards. The same reasoning

63. The term "venture capital cycle" belongs to Paul Gompers and Josh Lerner. GOMPERS \& LERNER, supra note 6.

64. See Black, supra note 5, at 781. 
applies with respect to any other permutation. The problem is in making the first two of the inputs available. The odd organizational form of the primary players in this market-Visa and MasterCard-seems to me to have been shaped by the need to respond to this problem. By organizing as (effectively) nonprofit cooperatives open to any bank, members could both cooperate in creating the network and competing intensely at the issuer level in order to attract customers and merchants. ${ }^{65}$

The government is the natural engineer to confront the venture capital simultaneity problem. While the government did not play an instrumental role in the development of the U.S. venture capital market, the idiosyncratic U.S. experience does not provide an example for other countries seeking to establish a venture capital market more quickly than through accretion. No institution other than the government has the right incentive to invest in the public good that results from establishing a venture capital market. The problem, however, is the mismatch of a government acting to create a market in which it has no long-term role. The response, I will argue, reflects the lesson of the U.S. experience and the character of the simultaneity problem. The government can act to induce the development of the necessary specialized financial intermediaries and also act to provide, in effect, seed capital, to the new market. That leaves the third factor necessary to solve the venture capital market simultaneity problem-entrepreneurs. Here the hypothesis is simply that the presence of a venture capital framework complete with funding will induce entrepreneurs to reveal themselves.

An understanding of the governmental role in engineering a venture capital market that $I$ have in mind can be seen from examining governmental efforts in three different countries: one early German failure that got every element wrong and whose failure highlights the shape of what is necessary for a successful government effort; a more recent Israeli effort that got much of the structure right; and a current Chilean program that was structured with precisely this analysis in mind. These examples are not intended to be illustrative of the wide range of government efforts to create a venture capital market. Rather, the goal is to highlight what is essential for a successful effort.

\section{A. The German "WFG" Experience}

The German WFG program ${ }^{66}$ provides a fascinating example of an early effort to create a national venture capital market that failed miserably. The

65. See generally David S. Evans \& Richard Schmalansee, Paying With Plastic: THE Digital REVOlution IN BUYING AND BorRowing ch. 13 (1999).

66. The abbreviation stands for "Deutsche Wagnisfinanzierungsgesellschaft," which translates roughly to "German Venture Financing Foundation." See RALF BECKER \& Thomas Hellmann, The Genesis of Venture Capital-Lessons from the German EXPERIENCE 2 (Working Paper, 2001). I have relied heavily on Becker and Hellman's careful account of this effort. 
nature of the program's failings, and its mirror image of the core of U.S. venture capital contracting, provide important guidance on the limits of governmental engineering.

Formed in 1975 at the insistence of the German federal government and with the express goal of developing a German venture capital market, WFG began with 10 million DM in funding, ultimately increased to 50 million DM, that was provided by twenty-nine German banks, including the largest banks and the leading savings and loan institutions. The banks' involvement was encouraged not just by governmental pressure, but also by a generous government guarantee: The government insured up to seventy-five percent of WFG's losses. As an inducement to entrepreneurs, WFG's return from a successful portfolio company investment was capped by the requirement that the entrepreneur be granted a call option to purchase WFG's position at cost plus a moderate interest rate. Thus, WFG had quite muted incentives to make successful investments. It was protected on the downside by the government guarantee, and limited on the upside to a moderate interest rate-a low risk (because of the guarantee) and a low return (because of the call option) investment, a strange vehicle indeed for investing in early stage, technology companies whose essential characteristic is their high risk.

WFG's governance structure reflected the program's government origin-a stakeholders' dream of a compromise. WFG had a twelve-person board, comprised of three bank members, three government members representing the ministries of commerce, finance, and research and development, two management consultants, two industry representatives, and two scientists. A mixed board committee selected the projects to be funded, pursuant to quite general criteria that nonetheless pointed in the right direction. The focus was to be on the innovative character of the project's technology, the existence of attractive commercial applications, and the quality of the entrepreneur.

WFG's investments were structured to be passive, perhaps because the return character of its investment gave it no incentive to be active. Only minority investments were made, and WFG received no control rights at all, even over important decisions. Consistent with this passive structure, WFG personnel provided no technological or management assistance to their portfolio companies even though the board members appeared to have the credentials to be useful.

Comparing U.S. venture capital practices with those of WFG reveals dramatic differences along every important dimension. Indeed, it would have been difficult for WFG to get the structure any more wrong. ${ }^{67}$

67. To some extent this comparison reflects a fair degree of hindsight bias: The U.S. venture capital contracting structure had not yet crystallized in 1975. However, Becker and Hellmann report that the deficiencies in the WFG structure were noted at the time. BECKER \& HELLMANN, supra note 66. 
In the United States, the venture capital contracting structure turns the Berle-Means problem on its head. Instead of assuming less control than their proportion of equity would dictate, venture capital investors in the United States take greater control positions than their proportion of equity. Not only do they obtain veto rights over major decisions, retain the continuation decision, and often control a majority of the board, but they also retain the right to terminate the entrepreneur. In contrast, WFG took a minority position in portfolio companies and obtained no control rights. An example highlights the difference. A recent study of a sample of Silicon Valley portfolio companies shows that professional managers replace more than half of founding entrepreneurs. ${ }^{68}$ WFG never replaced an entrepreneur.

Control and equity give U.S. venture capitalists the means and incentives to monitor highly incentivized managers. A twenty percent carried interest based on a one percent capital contribution gives them a huge stake in the upside. The impact of portfolio company failure on a venture capitalists' ability to raise subsequent funds and, hence, on the value of their human capital, assures that they also share the downside.

WFG lacked both the incentives to succeed and the means to monitor. Given the government guarantee and the entrepreneurs' call option, why should the banks have bothered to monitor? In all events, WFG lacked levers of control to act even if monitoring led to discovery of a problem. Control and equity also give U.S. venture investors the incentive to provide noncapital inputs to portfolio companies. WFG provided nothing but its initial capital investment.

The same dampening of WFG's incentives plainly influenced project selection as well. As already stressed, WFG's position was largely insulated from a portfolio company's performance. Not surprisingly, the same incentive pattern repeated itself at the level of the individual decision makers within WFG. No member of the board selection committee was either rewarded or penalized for WFG performance.

In short, WFG was a government program that created a financial intermediary that had no incentives, did not monitor, involved the government through board representation in project selection and, not surprisingly, produced dismal results. Over its lifetime, WFG experienced an internal rate of return of negative $25.07 \%$. In every year of its existence, proceeds from the government guarantee exceeded revenue from investments. In terms of addressing the simultaneity problem, WFG generated funds for venture investing, but created a hollow financial intermediary that was incapable of playing the central role that the U.S. venture capital contracting system contemplates. Keep in mind that a significant negative return for WFG necessarily parallels significant failures for the WFG-funded entrepreneurs. A pattern of failure will not call forth entrepreneurs.

68. Hellmann \& Puri, supra note 15 , at 182-83. 


\section{B. The Israeli Yozma Program}

In contrast to the early WFG program, a more recent Israeli program came closer to getting the incentive structure right. ${ }^{69}$ Plainly influenced by the American experience, the Israeli government established Yozma Ltd. in 1993 with the intention of creating the infrastructure for an Israeli venture capital market. In particular, Yozma created nine venture capital funds, in which it invested along with private investors. The structure of Yozma's participation in these funds was quite different than both the German government's and banks' participation in WFG.

First, Yozma provided no guarantee against loss. Rather, Yozma provided capital to the funds, matching up to forty percent of the capital invested by private investors. Thus, unlike WFG, private investors and the fund's managers bore their share of the downside risk.

Second, the Yozma structure preserved intense performance incentives on the upside. Like the German experience, Yozma's return on its investment was capped: The private investors had a call option on Yozma's investment at cost plus (1) a nominal interest rate and (2) seven percent of the future profits from portfolio company investments in which the fund was then invested. This cap, however, had very different incentive properties than the cap on WFG's return. Because Yozma's investment was made in a venture capital fund, rather than directly in the portfolio company as with WFG, and because the call option was held by the other investors rather than by the entrepreneur as with WFG, the returns to the financial intermediary were not capped at all. Rather, the cap served to leverage the returns, and therefore the incentives, of the intermediary instead of dampening them. WFG's subsidy to the banks and to the entrepreneur eliminated any incentive for WFG or its constituent banks to monitor the entrepreneur's conduct. In contrast, Yozma's subsidy to other investors increased their incentive to assure that the portfolio companies were carefully monitored.

Finally, Yozma did not make investment decisions. ${ }^{70}$ The fund's managers selected the portfolio companies in which the fund would invest. Thus, while Yozma's investments were passive like those of WFG, these passive investments were made through funds whose managers and other investors were highly incentivized. In this critical respect, the Yozma structure tracked the U.S. pattern of interposing a highly incentivized intermediary between passive investors and the portfolio company.

Yozma's performance was consistent with this more highly incentivized investment structure. Investment decisions were made by those who bore the

69. This discussion draws on Zohan Goshen, The ISRAEli Venture CAPITAL MARkET (Working Paper, 2001) (on file with author).

70. Through another program, Yozma made direct investments in portfolio companies, much as investors in a U.S. venture capital fund sometimes also have the right to invest directly in portfolio companies in which the fund invests. 
investment's risk and return. The Yozma funds ultimately increased in size to over $\$ 200$ million and in 1997 were successfully privatized.

\section{The Chilean CORFU Program}

A Chilean program begun in 2001, "designed to provide an incentive for the development of venture capital funding in Chile,"71 takes the Yozma concept a step further in the direction of the U.S. venture capital contracting model. The program contemplates that a government agency, the Corporation for the Incentive of Production (CORFU), will invest in privately managed venture capital funds organized roughly in accordance with the U.S. model. The fund manager's compensation has the same structure as developed in the United States-a $2.5 \%$ fixed annual fee on assets under management and a carried interest based on fund performance. Perhaps because of the early stage of the Chilean venture capital market, the program has a number of features that seem to be substitutes for the operation of a reputation market among venture capitalists.

First, the CORFU program seeks to insure more direct investor monitoring of the fund manager's performance rather than relying only on the structure of the fund manager's incentives and its investment in reputation. Each fund must have at least five unrelated investors holding at least ten percent of the fund's equity each, or at least one institutional investor holding at least twenty percent of the equity. By requiring the presence of large investors, the structure encourages internal monitoring of the fund manager.

Second, because the fund manager is likely to have a smaller investment in reputation at this stage of the development of a national venture capital market, the CORFU program requires a larger capital investment by the fund manager than the U.S. pattern of a one percent capital contribution by the general partner. The Chilean program requires the fund manager to invest at least fifteen percent of the fund manager's total assets in the managed fund. Note that the requirement is keyed to a percentage of the fund manager's assets, not of the fund's assets, an effort plainly directed to insure that even new fund managers-most local venture capitalists would necessarily be new-have a direct share of the downside.

CORFU investment in qualifying venture capital funds takes the form of "loans" that leverage the private investors' and the fund manager's equity stakes in the fund. While denominated as loans, the CORFU contribution is functionally preferred equity with a cap on return. The loan accrues interest at three percent with a term equal to the shorter of the life of the fund or fifteen years. No interest or principal payment is due until the fund makes a distribution to shareholders, and final payment occurs on liquidation. CORFU

71. CORP, FOR THE INCENTIVE OF PRoD., Venture CaPiTAL Program 1 (2001) (on file with author). 
has a distribution preference, receiving on liquidation first its principal and interest, following which the private investors receive an amount equal to their original investment. ${ }^{72}$ Then CORFU receives an amount equal to an annualized return of nine percent on the principal of the loan. The remaining funds are paid to the private investors and the fund manager.

Like the Yozma program, the Chilean program provides a subsidy to fund investors, including fund managers, through capping its return on its investment. Again, unlike the WFG program, the key feature of the CORFU program is its focus on the incentives of the financial intermediary. CORFU remains a passive investor in a venture capital fund whose investment structure, patterned after the U.S. model, is plainly intended to encourage the kind of active venture capital fund-portfolio company relationship found in the United States. ${ }^{73}$

\section{A TEMPLATE FOR GOVERNMENT ENGINEERING OF A VENTURE CAPITAL MARKET}

These three examples, together with the lessons of the U.S. venture capital contracting model, provide guidance in constructing a rough template for government efforts to engineer a venture capital market. The strategy reflects a central theme: The government should address the simultaneity problem by providing seed capital and helping to create the necessary financial intermediaries that together will encourage the supply of entrepreneurs, while at the same time maintaining the pattern of intense incentives coupled with intense monitoring that characterizes U.S. venture capital contracting.

Extending both the Yozma insight and the Chilean CORFU program, the government would issue a request for proposals for venture capital funds with the goal of selecting a number of funds run by competing professionals. The structure of these funds, and the structure of the fund-portfolio company contract, would generally track the U.S. pattern. A requirement of matching nongovernmental investors, as reflected in the CORFU program, provides interested monitors of the fund manager in the period prior to the operation of an effective reputation market.

Under this arrangement, the fund managers would have the incentive to seek out promising entrepreneurs, the experience to provide nonmonetary

72. CORFU receives $50 \%$ of any preliquidation distribution to fund investors. While the program document does not specify in greater detail other features of the fund's governance, CORFU has discretion to choose only funds that have satisfactory governance structures, and any postinvestment changes in governance require CORFU consent.

73. The author is grateful to LatinValley.com, the first fund manager to participate in the CORFU program, for copies of the program documentation. Prior to the adoption of the CORFU program, the author and principals in LatinValley.com made a presentation to the Economics Minister of Chile suggesting a general approach toward encouraging a Chilean venture capital market similar to that reflected in the CORFU program and in this Article. 
assistance in the development of the portfolio companies and, given the fixed term of the fund, the obligation to exit the investment when their noncapital inputs were no longer necessary. In turn, the government's participation as a passive investor in the fund allows the government to provide funds to the new market, but without itself participating in the capital allocation process.

This requirement of allocative passivity is central to carving out an effective governmental role in engineering a venture capital market. The most important flaw in the WFG model was the German government's creation of a financial intermediary with essentially no incentives to succeed. Direct funding by the government, the most common form of governmental assistance aimed at creating an entrepreneurial sector, has the potential to make things even worse through a kind of Gresham's law. Like WFG, the operators of direct government programs typically will lack the incentives to carefully monitor portfolio company management and also will be subject to political pressure over issues like management replacement and job maintenance. Additionally, those running direct government programs are unlikely to have the experience and incentives to provide portfolio companies with noncapital inputs (and efforts by the government, for example, to influence the decisions of potential suppliers to the portfolio company would run the obvious risk of political, as opposed to reputational, pressure).

To make matters worse, the flaws that arise from the government acting as the financial intermediary may well be attractive to entrepreneurs, who often view the monitoring and intervention of venture capitalists as unwanted intrusions. The best entrepreneurs may then prefer the government program to private venture capital funds, and more frequently fail because they will lack the benefits associated with an experienced financial intermediary and a proper incentive and monitoring structure. This leaves the less-talented entrepreneurs to operate in the private sector, where they will fail more frequently, thereby discouraging development of private sector financial intermediaries and decreasing the supply of entrepreneurs. In short, a misconceived government plan can operate perversely to actually discourage the development of a private venture capital market.

To be sure, even if the government invests in a private venture capital fund that formally allocates the government a passive role, a realist would fear that the government still might try to influence the selection of portfolio companies (and the interaction between the venture capital fund and the portfolio company) informally through the implicit promise of future government funding. Such an effort presents the fund manager with a tradeoff. Fund managers whose initial efforts are successful will have the capacity to attract private investors for future funds; in other words, the market makes an implicit promise of future investment conditioned only on performance and without the risk of opportunistic breach. In contrast, making politically influenced portfolio decisions reduces the likelihood of the fund's success, thereby reducing the value of fund manager's carried interest. In turn, the reduced 
success of the fund makes it more difficult for the fund manager to secure private investors for future funds.

The result, then, of acceding to the government's effort at informal influence is to substitute the government's implicit promise of future funding for that of the market. A fund manager would have reason to question the credibility of the government's implicit promise-implicit promises typically require the support of reputational sanction for breach that is lacking in the government setting. ${ }^{74}$ Moreover, the reduced access to the market for future funding as a result of reduced success due to government meddling serves to render the fund manager's human capital investment specific to its relation with the government, thereby creating the potential for subsequent opportunistic conduct by the government. To be sure, a government retains the means to pressure fund managers if it loses sight of why it is engaged in the effort to engineer a venture capital market in the first place, but that is true of any government involvement, and the proposed structure both limits that effort to the informal, and creates important incentives for the fund manager to resist.

This model of channeling government efforts to assist in creating a market into passive investment through incentivized intermediaries has an interesting, if inadvertent, precedent in the United States. Early in the development of the leveraged buyout movements, state pension funds were among Kohlberg Kravis Roberts's (KKR) earliest investors. ${ }^{75}$ These early passive investments in KKR had the unintended consequence of providing government support for the development of a private equity market, through an intensely incentivized financial intermediary, with precisely the results hoped for here: Successful performance by early KKR funds attracted much more private investment into the private equity market, led to the creation of many more funds, and generally fueled the private equity market's restructuring of U.S. industry. ${ }^{76}$

\section{QUALIFICATIONS AND CONCLUSION}

Any effort at financial engineering should close with qualifications. However clever the blueprint, there will always be more moving parts than the

74. The U.S. savings and loan (S\&L) industry provides a recent local example of the difficulty of relying on a government's reputation. In an effort to encourage stronger (relatively) S\&Ls to acquire failing S\&Ls and thereby reduce the likelihood of a call on government deposit insurance, the Federal Home Loan Bank Board entered into contracts that allowed the acquiring $\mathrm{S} \& \mathrm{~L}$ to use a purely accounting construct-supervisory goodwill-to meet regulatory capital requirements, either a subsidy or an exemption depending on the characterization. A few years later, Congress reneged on the contract by passing legislation that eliminated supervisory capital. See United States v. Winstar Corp., 518 U.S. 839 (1996). Governmental opportunism is hardly limited to non-first world countries.

75. George P. Baker \& George David Smith, The New Financial Capitalists: KoHlberg Kravis Roberts and THE CREATION OF Corporate VAlue 79-80 (1998).

76. Id. 
engineers contemplate. In the case of a government effort to engineer a venture capital market through passive investment in a highly incentivized intermediary, the major qualification arises from the way I have framed the simultaneity problem. The supply of entrepreneurs was treated as solely a function of the availability of funds and specialized intermediaries - if we build it, the entrepreneurs will come. But what about an entrepreneurial culture as a precondition of a venture capital market? Why not a three-factor simultaneity model, instead of only two?

Two recent papers assessing the slow development of a German venture capital market, even after funds and intermediaries were said to be available, argue that Germany lacked the appropriate entrepreneurial culture, with those having the skills necessary to form technology based start-ups lacking the tolerance for uncertainty critical to leaving the nest of large firm employment. In this view, the final elements necessary to launch a German early stage venture capital market was the Internet explosion, and a large number of Germans having been exposed to the U.S. business culture, especially through business school training. ${ }^{77}$

To some extent the cultural criticism can be deflected. One characterization of the criticism is that the success of venture capital-backed Internet start-ups changed the culture, thereby providing the final element necessary to engineering a venture capital market. But this is simply rephrasing the simultaneity analysis I have offered, albeit with an intermediate step: Providing capital and incentivized financial intermediaries attracts some entrepreneurs whose success, in turn, attracts still more entrepreneurs. Stated more generally, a cultural change occurs between the government's engineering effort and the appearance of the market.

I readily confess my discomfort with an easy recourse to culture as an explanation for when a high technology venture capital market (or any other economic institution) develops. ${ }^{78}$ Too many degrees of freedom are left with respect to the direction of causation and with respect to defining the variables. Nonetheless, I cannot avoid a nagging doubt that my two-factor simultaneity model, like the two-factor asset pricing model, may turn out to be analytically lovely but empirically challenged. ${ }^{79}$ Different countries may respond quite

77. BeCKer \& HellmanN, supra note 66 , at 20-21; Marc-Oliver Fiedler \& Thomas Hellmann, Against All Odds: The Late but Rapid Development of the German Venture Capital Industry, J. PRIVATE EQUITY, Fall 2001, at 31, 35-36.

78. See Black \& Gilson, supra note 15, at 271-72; Ronald J. Gilson \& Mark J. Roe, Lifetime Employment: Labor Peace and the Evolution of Japanese Corporate Governance, 99 COLUM. L. REV. 508, 517 (1999).

79. The respected economic historian Peter Temin makes the case for a culturally embedded approach to economic history. See Peter Temin, Is It Kosher to Talk About Culture?, 57 J. ECON. HIST. 267 (1997). However, his account leaves open the devilish issues of causation. It would hardly be surprising that cultural mores and economic institutions generally are consistent, thereby leaving the causative issue open. The more interesting and unusual circumstance is when they differ. 
differently to the same engineering efforts. As with the two-factor asset pricing model, other factors may explain the empirical results in ways that turn out to be difficult to explain analytically even though their presence is revealed empirically. Should that prove true, the consolation will be that the engineering effort still will have taught us something important by more clearly framing the phenomenon that then needs explanation, but now with a range of experience in different countries that will require more disciplined analysis than the cultural account has provided to date. 